\title{
SIMMENTAL CATTLE BREED IN DIFFERENT PRODUCTION SYSTEMS
}

\author{
P. Perišić ${ }^{1}$, Z. Skalicki ${ }^{1}$, M. M. Petrović ${ }^{2}$, V. Bogdanović ${ }^{1}$, D. Ružić- \\ Muslić $^{2}$ \\ ${ }^{1}$ Faculty of Agriculture, 11080, Belgrade-Zemun, Republic of Serbia \\ ${ }^{2}$ Institute for Animal Husbandry, 11080, Belgrade-Zemun, Republic of Serbia \\ Corresponding author: perisicp@agrif.bg.ac.rs \\ Invited paper
}

Abstract: The paper gives the analysis on the state in population of Simmental cattle reared in Europe with a special review on the state in Simmental cattle in our country which makes about $80 \%$ total cattle fund in Serbia, and is characterized by a negative trend in the number of cattle, as well as by a low average milk production per cow. The most important results obtained by both domestic and foreign authors by means of various methods of improving Simmental breed and its raising in different systems have been shown. The directions for improving Simmental cattle according to the productive directions have been analyzed. Possible methods of improving the Simmental cattle in our country have been pointed out, which should be in accordance with already existing genetic potential of each actual population, its purpose (registered breeding stock, production breeding stock), as well as with the market needs for cow milk, milk products and meat (primarily beef meat, for export). A special emphasis has been given to the importance of organizing the production of meat in the cow-calf system in which Simmental breed, following the model of many European countries, should have good performance also in our country, if the same production should be organized in deserted hilly and mountainous regions. In this way we could contribute to more significant increase in overall beef production, and to reactivate unused natural resources as well.

Key words: production of meat, production of milk, Simmental breed

\section{Introduction}

Simmental breed is mostly grown in central Serbia, as a breed of combined production traits. In the regions with more intensive cattle production the cattle populations with pronounced milk yield are reared, and very often there are cases of cross-breeding the Simmental breed with dairy breeds. In hilly-mountainous regions low performance animals intended for meat-milk production are reared. 
A milk yield in registered Simmental cows in Serbia, according to selection reports, ranges from $4000 \mathrm{~kg}$ to $5000 \mathrm{~kg}$ milk in standard lactation, depending on the lactation in order and rearing region, while estimations for milk yield in cows which are not under control state the milk yield of about $3000 \mathrm{~kg}$ although those records are not fully reliable.

\section{The state in Simmental breed in some European countries}

Simmental breed is the second important breed in Europe, following the group of Holstein Friesian cattle and holsteinized populations, if an overall importance of breeds is taken into consideration (the size of the breed population, milk production, meat production). According to the reports of the associations for Simmental breed in some European countries (www.Cattlenetwork.net), absolutely largest population of Simmental cattle is in Germany (about 3500000 heads or a little less than $30 \%$ of total cattle fund in Germany), Austria (1600000 to 1700000 heads or about $80 \%$ total fund of cattle in Austria), Serbia (about 850000 heads or about $80 \%$ fund of cattle of Serbia), followed by Czech Republic, Switzerland and Slovenia.

In the process of creating the populations of Simmental breed for high milk yield, besides intensive selection in pure breed, a meliorative cross-breeding of Simmental with dairy breeds, primarily Red-Holstein, was carried out. In this way, the Simmental breed populations with very pronounced milk yield and milking traits were created, and the breeding goals and programmes were being defined especially for them.

Table 1. Milk yield of Simmental cows in some European countries

\begin{tabular}{|l|c|c|c|c|c|c|c|}
\hline \multicolumn{1}{|c|}{ Country } & Year & $\begin{array}{c}\text { Lactation, } \\
\text { day }\end{array}$ & $\begin{array}{c}\text { Milk, } \\
\text { kg }\end{array}$ & Fat,\% & $\begin{array}{c}\text { Fat, } \\
\text { kg }\end{array}$ & Proteins, \% & Proteins,kg \\
\hline Hungary & 2004 & 293 & 5023 & 3,99 & 201 & 3,43 & 175 \\
\hline Czech Republic & 2006 & 294 & 6162 & 4,08 & 252 & 3,46 & 213 \\
\hline Slovenia & 2006 & 305 & 5023 & 4,17 & 209 & 3,29 & 165 \\
\hline Slovakia & 2004 & 297 & 4919 & 4,09 & 201 & 3,30 & 162 \\
\hline Fleckvieh Switzerland & 2006 & 299 & 6847 & 3,99 & 273 & 3,24 & 222 \\
\hline Simental Switzerland & 2006 & 297 & 5681 & 3,88 & 220 & 3,30 & 187 \\
\hline Austria & 2006 & 305 & 6483 & 4,18 & 271 & 3,43 & 222 \\
\hline Norway & 2004 & 266 & 5229 & 4,15 & 217 & 3,35 & 175 \\
\hline Croatia & 2006 & 305 & 4459 & 4,07 & 181 & 3,35 & 149 \\
\hline Italy & 2006 & 293 & 6528 & 3,92 & 256 & 3,41 & 223 \\
\hline (Monb.) France & 2006 & 296 & 6907 & 3,91 & 270 & 3,46 & 239 \\
\hline Germany & 2006 & 316 & 6854 & 4,14 & 284 & 3,48 & 239 \\
\hline Poland & 2006 & & 4785 & 4,01 & 192 & 3,36 & 161 \\
\hline
\end{tabular}

(www.Cattlenetwork.net) 
From its creation to nowadays, the directions in improving the Simmental breed were often changed, but the necessity to preserve its dual production with differences regarding the productive traits (milk yield or fattening) were seen as an aim, reconciled with the need of the countries in which the same breed has been raised for the purpose of combined production. In the last several decades in nonEuropean and some European countries the Simmental breed was raised primarily for a specialized production of meat, by breeding in pure breed or by crossbreeding with other breeds. Milk yield of Simmental cows in European countries rearing this breed for milk and meat can be seen in Table 1 .

\section{The importance of some traits at defining breeding programmes for Simmental breed}

As regards breeding goals and programmes for Simmental breed in European countries they differ among each other. Undoubtedly, they must be reconciled with the needs of every country for answering the demands on home market for milk and meat. Selection goals depend much both on the size of the Simmental population and its share in total cattle fund of a given country. An important factor that influences the defining of productive goals for Simmental breed is also a share of dairy cattle in total cattle fund and their productivity. The greater the participation of dairy breeds in some country, especially if their milk yield is high and is still going up, the more direct influence there is on the decrease in the population of Simmental cattle reared for combined production with the increase in the populations reared in the "cow-calf" system.

Table 2. Importance of individual traits (in \%) in selection goal for Simmental breed

\begin{tabular}{|l|c|c|c|c|}
\hline \multicolumn{1}{|c|}{ Country } & Milk & Meat & Fitness & Exterior \\
\hline Hungary & 60 & 40 & 0 & 0 \\
\hline Czech Republic & 40 & 24 & 0 & 36 \\
\hline Slovenia & 45 & 10 & 23 & 22 \\
\hline Slovakia & 60 & 40 & 0 & 0 \\
\hline Serbia & 50 & 50 & 0 & 0 \\
\hline (Fleckvieh) Switzerland & 40 & 10 & 30 & 20 \\
\hline (Simental) Switzerland & 35 & 20 & 25 & 0 \\
\hline Romania & 60 & 35 & 5 & 0 \\
\hline Poland & 50 & 50 & 0 & 0 \\
\hline Austria & 38 & 16 & 46 & 0 \\
\hline Croatia & 50 & 50 & 0 & 19,5 \\
\hline Italy & 44 & 24 & 12,5 & 18 \\
\hline (Simmental) France & 51 & - & 31 & 0 \\
\hline (Monbeliard) France & 50 & - & 37,5 & \\
\hline Germany & 38 & 16 & 46 & \\
\hline
\end{tabular}

(www.Cattlenetwork.net) 
The importance of some traits in selection goals for Simmental breed in some European countries is shown in Table 2. Functional traits have a great importance in selection goals and breeding programmes for Simmental breed populations that realize a high average production of milk in lactation (Simmental breed in Germany, Austria, Switzerland...), so that in future period we can expect greater improvement in functional traits (longevity, regular fertility, resistance to mastitis), in relation to further increase in milk yield.

Steinwidder and Greimel (1999) studied the effect of longevity and level of milk production on profitability of dairy cattle. The records of all Austrian Simmental cows which ended their production between 1975 and 1998 were grouped according to longevity (2, 3, 9, 10 lactations) and milk production (average, best 10000, 5000, 1000, 500 and 50 cows best in every lactation group). The increase in milk yield led to longer lactations and less number in calves born annualy. Total expenses per cow and year varied slightly within the cow groups divided into production levels. Profit per cow and year increased lineary with the increase in milk yield, and digressively with longevity. It was confirmed that a significant increase in the profit per farm is the result of increased longevity of up to 6 lactations. After the sixth lactation the rate of increase in profit per farm decreased to 9 concluded lactations.

\section{The improving of Simmental breed in the direction of dual production}

The improvement in the milk yield and fattening traits in Simmental breed was performed primarily by selection in pure breed in which way the old classic type of Simmental breed was created, of hard constitution and not strongly pronounced traits of milk yield. The traits of milkiness were lagging far behind in the relation to the same traits in specialized dairy breeds. In the European countries which besides Simmental breed rear, in a significant degree, some other diary breeds (Black-White and Red-White Friesian breed, Black-Brown breed), Simmental breed was not imposed in the improving milk yield with the aggravation of fattening and slaughtering traits. Such a situation was present in Germany mostly, and in lesser degree in Austria, and selection work was trying to equal improvement both in the fattening and milk yield traits. Holsteinization of Simmental breed (by Red Holstein) was in lower degree present in Germany, and even lower in Austria, taking into consideration that these two countries are the major exporters of breeding animals and Simmental bulls semen. Simmental cattle was imported to our region mostly from Austria and Germany, so a number of researchers from our country studied the productive traits of the imported cattle from those countries (Skalicki, 1980; Perišić, 1998). The other reason for slight 
application of cross-breeding Simmental with Holstein is the existence of quotas for the production of milk, which were relevant in the last decades.

In European countries, where in the last third of the last century, Simmental breed and cattle were dominant in total cattle fund of Simmental breed, in order to improve the Simmental breed its cross-breeding with dairy breeds was carried out. The range of these measures was different, regarding the size of population included by this way of improvement and also by different gene share of dairy breeds in inheritance foundation in newly created more productive Simmental populations.

By use of cross-breeding the traits of milk yield and milkiness in Simmental breed improved more rapidly, so this method of improvement was widely present in Switzerland due to increased needs for milk in the last two decades of the last century. Similar situation was present in other European countries as well (Hungary, Czech Republic, Slovakia), which in their cattle fund had a considerable share of Simmental which was of far greater productivity in comparison with the populations grown in Switzerland. The above mentioned countries had a task to increase an overall milk production in the shortest time possible. The fastest way to achieve this goal was the mass cross-breeding of Simmental with Holstein breed (Red-White, Black-White), where the effects of cross-breeding could be seen in the research results by Michel et al. (1989), Ruban and Todorov (1990), Strapaka and Strapakova (1997) and other authors, as well as in the comparison of average values in milk yield parameters in Simmental cow populations (Table 2).

Bigler (2001) stated the performance results in Switzerland Simmental breed, other Simmental breeds, Montbeliard, Red-White Holstein and Black-White Holstein for 2000/2001. The share of inheritance of Red-White Holstein in Switzerland Simmental, Montbeliard and other Simmental breeds was 2.3\%, $2.1 \%$ and $56.4 \%$. The age at first calving ranged from 28.83 months in Holstein to 32.58 months in Montbeliard. The age at culling ranged from 53.3 months in Holstein to 78.4 months in Switzerland Simmental. The milk yield in lactation in these 5 breeds was on average $6077 \mathrm{~kg}, 6705 \mathrm{~kg}, 7194 \mathrm{~kg}, 7045 \mathrm{~kg}$ and $7299 \mathrm{~kg}$, the share of milk fat $3.93 \%, 4.04 \%, 3.77 \%, 4.04 \%$ and $3.96 \%$, and a share of protein 3.35 $\%, 3.24 \%, 3.31 \%, 3.22 \%$ and $3.21 \%$.

In the last decade, the number of cows in pure Simmental breed (without share of genes of dairy breeds) has been gradually increasing due to changed demands in the quantities needed for cow milk. In our country as well, following the example of some European countries, a meliorative cross-breeding of Simmental with Red Holstein or Montbeliard breed is present in a considerable degree. A number of researchers studied the effects of the Simmental cattle import, as well as the cross-breeding of Simmental with Red Holstein. Reproductive and productive traits of Simmental cows and the crossbreds of Simmental and Red 
Holstein Friesian breed were studied by Zečević (1986), Perišić et al. (1999ab, 2002abc, 2004, 2006ab), Perišic (2007) and other authors. The results of these authors suggest mostly that crossbreds in relation to Simmental breed are somewhat more early in maturing, produce more milk with lower content of milk fat and have slightly poorer reproductive traits. The most important improvement in the appearance and structure of the udders, present in Simmental and Red-White Holstein crossbreds, is the equalizing in the udders fourths and udder index, increase in the udder largeness, better fixation of udders and better form and size of teats. The defects present which do not hinder the function of udders but only violate the appearance, such as for example, classic non-active teats (supernumerary teats) on the dairy mirror, as well as active accessory teats and intrateats, are related more to the population within the breed and are not breed characteristics. According to the results of Brka et al. (2002), the frequency of supernumerary teats was $44.3 \%$ in German Simmental breed and $31.2 \%$ in German Switzerland White breed. These values for the frequency of the occurrence of accessory teats according to these authors were relatively high when compared with the values cited by the same authors for Holstein with a share of $15 \%$ (Brka et al., 2002) and $20 \%$ and Simmental $69 \%$, citation per Brka et al. 2002). From the above mentioned it can be concluded that at cross-breeding aimed at improving both the traits of milk yield and milkiness, the selection must also be simultaneoulsy performed, especially selection of bulls as regards the demonstration of the defects of udders what can be confirmed by a progeny test.

\section{Simmental in the cow-calf system}

Simmental breed has good fattening and slaughtering qualities, which it displays when raised in pure breed, and it transfers them into the crossbreds when commercial cross-breeding with dairy or fattening breeds is conducted. Fattening and slaughtering traits in Simmental cattle raised in the system cow-calf, do not usually lag behind classic fattening breeds, primarily terminal ones. Simmental breed is treated as a classic fattening breed in Great Britain, Denmark, the Netherlands, Scandinavian countries and all non-European countries. By its raising in the cow-calf system Simmental breed has the performance much closer to terminal fattening breeds (Sharolais, Limousine), than in well-known British fattening breeds. In the mentioned countries the type of Simmental breed with pronounced fattening traits, great frames and strong constitution is raised. The test results on the fattening in young Simmental bulls are in Table 3. showing that the liveweight gains obtained in the test up to the age of one year are always higher in young bulls originating from the populations intended for specialized meat production. 
Table 3. The results of test on fattening in young Simmental bulls

\begin{tabular}{|l|c|c|c|c|c|}
\hline \multicolumn{1}{|c|}{ Country } & Year & $\begin{array}{c}\text { Body } \\
\text { weight at } \\
\text { birth, kg }\end{array}$ & $\begin{array}{c}\text { Body } \\
\text { weight at } \\
200 \text { day, kg }\end{array}$ & $\begin{array}{c}\text { Body weight } \\
\text { at 365 day, } \\
\mathrm{kg}\end{array}$ & $\begin{array}{c}\text { Everage daily } \\
\text { gain, g }\end{array}$ \\
\hline Czech Republic & 2006 & 39 & 284 & 531 & 1348 \\
\hline Slovenia & 2006 & 45 & 276 & - & - \\
\hline Slovakia & 2004 & 32 & 202 & - & - \\
\hline Serbia & 2004 & 45 & 251 & 508 & 1254 \\
\hline (Simmental) Switzerland & 2006 & 43 & 311 & 536 & 1469 \\
\hline Sweden & 2006 & 48 & 342 & 610 & 1470 \\
\hline Austria & 2006 & 44 & 285 & 445 & 1103 \\
\hline Norway & 2004 & 44 & 340 & 568 & 1492 \\
\hline Ireland & 2004 & 40 & 400 & - & - \\
\hline Great Britain & 2004 & 41 & 422 & 600 & 1530 \\
\hline Germany & 2006 & 41 & 286 & 525 & 1326 \\
\hline Danemark & 2006 & 47 & 355 & 636 & 1614 \\
\hline
\end{tabular}

(www.Cattlenetwork.net)

As a maternal foundation, Simmental breed is used at large in specialized systems for meat production ("cow-calf"system), where the cross-breeding with terminal fattening breeds (Sharolais, Limousine, Belgian Blue-White) is most often organized.

In central European and eastern European countries Simmental breed is more often used in different programmes of cross-breeding with other fattening breeds in the case when it is grown in the cow-calf system. Thus Deblitz et al. (1992) in the eastern Germany studied the effects of outdoor rearing on 221 herds of pure bred nursing cows and crossbreds of Galloway, Montafon, Limousine, German Red, German Angus, Aberdeen-Angus, Sharolais and Simmental nursing cows on reproductive results and production of young bulls. The animals were held outside in $40 \%$ herd during winter. Number of young bulls weaned per cow ranged from 0.87 for rougher breeds to 0.91 for large breeds (Sharolais and Simmental), but there were not significant differences between breeds in the weight of young bulls produced at $100 \mathrm{~kg}$ of cow body mass. The cost of feeding was $15 \%$ higher for the cows that spent the winter outside in relation to cows kept in stable. It was concluded that, under the conditions which are dominant in Germany, the outdoor rearing of cattle of small breeds has certain advantages.

Mazurovsky and Litovchenko (2001) presented results on creation a new meaty type of Simmental cattle in the region of Orenburg (Russia). During the creation of pure breed meaty type of Simmental, the best performance during the first phase was obtained by the animals produced from the bulls of German and Canadian selection. During the introductory cross-breeding the use of Limousine breed showed good effect. During the first phase, an average liveweight gain in 
fattening was 1300-1400 g daily, and when the animals were slaughtered in the age of 24 months the yield of meat in carcass weighted $380-395 \mathrm{~kg}$.

Tschumperlin et al. (2001) compared the productive efficiency of dualpurpose medium sized Simmental cows and Aberdeen-Angus cows. A wholle herd was mated with Angus bulls. The young bulls Simmental x Aberdeen-Angus had a higher liveweight gain in live body weight and net mass in relation to pure bred Angus young bulls. Simental x Angus young bulls had a higher yield of meat and better meat quality in relation to Angus young bulls (difference of $0.6 \%$ and $1.0 \%$ ). A superiority of dual-purpose type of cows in relation to a specialized fattening type in this system of meat production is caused mostly by a higher milk yield in Simmental cows.

In our production systems (half-intensive fattening), which lasted up to the age of 16 months, according to the results of Perišić (2007) young bulls of different genotypes realized following average liveweight gains: young bulls of Simmental breed $1190 \mathrm{~g}$, young bulls of $\mathrm{F}_{1}$ (Simmental x Limousine) $1250 \mathrm{~g}$ and young bulls of $F_{1}$ (Simmental $x$ Sharolais) $1275 \mathrm{~g}$. In the same research the effect of the age of bulls at slaughtering was studied (duration of fattening), as a linear regression factor, at which the coefficients obtained were very highly significant $(\mathrm{P}<0.001)$ and highly-significant $(\mathrm{P}<0.01)$. It was confirmed that with the increase of age in bulls at slaughtering in relation to average established age there occurrs the increase in bulls body mass along with the decrease in daily liveweight gain as well. Energy needs for creating kilograms of liveweight gain are increased with aging (due to the increased share of fat), so the liveweight gains are lower.

The importance of Simmental breed, besides its good results at crossbreeding with other cattle breeds, is also seen in cross-breeding with Zebu cattle, in which process it transfers its good traits into the hybrids. In this way classic industrial cross-breeding for the purpose of obtaining $F_{1}$ hybrid of Simmental breed and Zebu cattle is performed, and a great number of fattening breeds are created on the basis of cross-breeding of Simmental breed and Zebu. Thanks to a good adaptibility, Simmental breed has spread from Europe to all continents and different climate regions, where it is mostly reared in the system cow-calf, in pure breed or is being crossed with fattening breeds of cattle or Zebu breeds. Thus in the African continent Simmental breed is mostly used for the cross-breeding with local Zebu breeds (Grupp, 1994), and it is important to say that for a tropical regions Simmental cattle with curly hair is not appropriate what should be given attention to when making the choice of the bull semen or bulls themselves.

General prerequisites for a success and economics of meat production in the cow-calf system, besides pronounced fattening qualities of Simmental breed, are also regular fertility and the existence of the conditions for fattening with smallest possible feeding cost (use of pastures, green fodder). In order to achieve the maximal possible fertility the induction and oestrus synhronization should be 
regularly applied. In this way the shortening of the duration of the service period could be influenced upon, and increase the \% of twinning by a controlled increased doses of applied hormone (per type FSH), what is of great importance in this production. The calvings should be planned in accordance with real climate conditions in a given region, on purpose to utilize maximally the vegetation period (pasture) by cows and calves.

\section{Conclusion}

On the basis of the stated research results obtained by domestic and foreign authors when studying the productive traits in Simmental breed in different rearing systems, a remarkably lower milk production in Simmental breed in our country is perceived in relation to an average production realized by the animals of Simmental breed in majority of European countries. Such a state in production points to a more intensive improving work for the purpose of improving the milk yield traits in Simmental breed. An applied method of improvement in some populations should be reconciled with already existing genetic potential of each actual population, its purpose (registered breeding stock, productive breeding stock), and the market needs for cow milk and dairy products as well.

In European countries a trend of decreasing the number of milking cows is present (because of realized high milk yields per cow in specialized dairy breeds, and milk supplies as well), what results in the increase of population of cattle intended for meat production raised in the system cow-calf. In Serbia there are huge unused potentials in deserted hilly and mountainous regions which could most easily be reactivated by organizing the production of beef per system cowcalf. With the aim of overcoming the problems which should appear during organizing this production (unattractive production, difficult to find people for work, low accumulation, production risks), by a state stimulative measures (for example subsidies per cow reared in the system cow-calf), the organization of this production could be influenced upon on a large scale. By this way the realization of two goals would be approached at the same time:

- Reactivation of unused natural resources and revitalization of deserted regions (strategic goal in most European countries),

- Increase in the beef production (especially beef for export), taking into consideration that in the last several years even the smallest export quotas were not realized. 


\title{
Simentalska rasa goveda u različitim sistemima proizvodnje
}

\author{
P. Perišić, Z. Skalicki, M. M. Petrović, V. Bogdanović, D. Ružić-Muslić
}

\section{Rezime}

Analizirano je stanje u populaciji simentalskih goveda koja se gaje u Evropi, sa posebnim osvrtom na stanje simentalske rase kod nas, koja u poslednje dve decenije čini između 80 i $85 \%$ ukupnog fonda goveda Srbije, a koju prati negativni trend brojnosti (veličini populacije), kao i niska prosečna proizvodnja mleka po kravi. Analizirani su pravci oplemenjivanja simentalskih goveda u skladu sa smerovima proizvodnje. Ukazano je na moguće metode oplemenjivanja simentalske rase kod nas, koje bi morale biti u skladu sa postojećim genetskim potencijalom svake konkretne populacije, njenom namenom (matični zapati, proizvodni zapati), kao i u skladu sa potrebama tržišta za kravljim mlekom i mlečnim proizvodima. Kao metod oplemenjivanja simentalske rase kombinovanog smera proizvodnje do sada je više primenjivan metod selekcije u čistoj rasi. Metod meliorativnog ukrštanja simentalske rase sa crvenim holštajnom je značajno manje u primeni i više ga sprovode odgajivači proizvodnih zapata goveda simentalske rase.

Poseban akcenat je dat značaju organizovanja proizvodnje mesa u sistemu krava-tele, gde bi simentalska rasa po uzoru na mnoge evropske zemlje i kod nas dala dobre rezultate, ako bi se ista proizvodnja organizovala u napuštenim brdskim i planinskim područjima. Na ovaj način bi se moglo doprineti značajnijem povećanju ukupne proizvodnje junećeg mesa, kao i aktiviranju neiskorišćenih prirodnih resursa, što bi predstavljalo strateški interes države. U cilju povećanja ekonomičnosti u proizvodnji u sistemu krava-tele, neophodno je postizanje maksimalne plodnosti, iz kog razloga bi trebalo redovno primenjivati indukciju i sinhronizaciju estrusa. Sezonu telenja treba planirati u skladu sa konkretnim klimatskim prilikama na konkretnom području, a sve u cilju maksimalnog korišćenja perioda vegetacije (paše) od strane krava i teladi.

\section{References}

BIGLER A. (2001): Performance increased further.Weitere Auswertungen im Geschaftsjahr 2000/2001, Leistungen weiter gestiegen. Schweizer Fleckvieh, 7, 3743.

BRKA M., REINSCH N., KALIM E. (2002): Frequency and Heritability of Supernumerary Teats in German Simmental and German Brown Swiss Cows. Journal of Dairy Science, 85, 1881-1886. 
GRUUP T. (1994): The changing history of the breeding of German Simmental cattle in Namibia. Tierzuchter, 46: 7, 34-37.

DEBLITZ C., BUCHWALD J., BALLIET U., RUMP M. (1992): Profitable use of extensive pasture. Tierzuchter, 44, 4, 26-29.

MAZUROVSKY L.Z., LITOVCHENKO V.G. (2001): Creation of a new beef type of the Simmental cattle breed. Russian-Agricultural-Sciences, 9, 39-43.

MICHEL A., LEUENBERGER H., KUNZI N. (1989): Optimales erstkalbealter fur gealpte rinder unterschiedlicher zuchtrichtung. Simentaler Fleckvieh, 6,15-19.

PERIŠIĆ P. (1998): Reproduktivne i proizvodne osobine različitih genotipova krava simentalske rase. Magistarska teza, Poljoprivredni fakultet, Beograd.

PERIŠIĆ P., SKALICKI Z., PETROVIĆ M.M., MIŠČEVIĆ B., RUŽIĆ D., DELIĆ N. (1999a): Uticaj genetskih i nekih paragenetskih faktora na prinos mleka krava simentalske rase. Biotehnologija u stočarstvu, 15, 1-2, 29-39.

PERIŠIĆ P., SKALICKI Z., LATINOVIĆ D., PETROVIĆ M.M., RUŽIĆ D. (1999b): Uticaj uzrasta pri prvoj oplodnji na neke reproduktivne i proizvodne osobine prvotelki simentalske rase. Savremena poljoprivreda, 48, 1-2, 155-159.

PERIŠIĆ P., SKALICKI Z., PETROVIĆ M.M., MEKIĆ C., ĐEDOVIĆ R. (2002a): Uticaj uzrasta pri prvoj oplodnji na proizvodne osobine krava simentalske rase. Savrernena poljoprivreda, 51, 3-4, 97-101.

PERIŠIĆ P., SKALICKI Z., PETROVIĆ M.M. (2002b): Uticaj uzrasta pri prvoj oplodnji na neke reproduktivne i proizvodne osobine krava simentalske rase u prve tri laktacije. Biotehnologija u stočarstvu, 18, 1-2, 17-23.

PERIŠIĆ P., SKALICKI Z., LATINOVIĆ D., TRIFUNOVIĆ G., BOGDANOVIĆ V. (2002c): Uticaj udela gena crvenog holštajna na reproduktivne i proizvodne osobine krava simentalske rase. Biotehnologija u stočarstvu, 18, 5-6, 37-43

PERIŠIĆ P., SKALICKI Z., MEKIĆ C., TRIFUNOVIĆ G. (2004): Uticaj udela gena crvenog holštajna na reproduktivne i proizvodne osobine prvotelki simentalske rase. XVIII savetovanje agronoma, veterinara i tehnologa. Zbornik naučnih radova, Institut PKB agroekonomik, 10, 2, 25-30.

PERIŠIĆ P., SKALICKI Z., BOGDANOVIĆ V., TRIFUNOVIĆ G., ĐEDOVIĆ R. (2006a): The influence of Red Holstein gene share on reproduction and production traits of first-calf heifers. Book of Abstracts of the $57^{\text {th }}$ Annual Meeting of the EAAP, 17-20 September, Antaliya, Turkey, 35.

PERIŠIĆ P., SKALICKI Z., PETROVIĆ M.M., BOGDANOVIĆ V. (2006b): Simentalska rasa i pravci njenog razvoja. XVII Inovacije u stočarstvu, Biotechnology in Animal Husbandry, 22, poseban broj, 231-244.

PERIŠIĆ P. (2007): "Reproduktivne i proizvodne osobine simentalske rase pri kombinovanom smeru proizvodnje i sistemu krava-tele", Doktorska disertacija, Poljoprivredni fakultet, Beograd-Zemun. 
RUBAN J., TODOROV T.G. (1990): Karakter laktacionnoj dejateljnosti simmentaljskogo skota različnih pomecnih sočetanij. Povišenie produktivnosti krupnogo rogatogo skota i ovec, 36-41.

SKALICKI Z. (1980): Fenotipska varijabilnost i povezanost reproduktivnih i proizvodnih osobina austrijskog i nemačkog simentalca $u$ istim uslovima odgajivanja. Magistarski rad.

STEINWIDDER A., GREIMEL M. (1999): Economic evaluation of the longevity of dairy cows. Bodenkultur, 50, 4, 235-249.

STRAPAK P., STRAPAKOVA E. (1997): Milk Production of imported fleckvieh cows. Biotechnology in Animal Husbandry, 13, 5-6, 281-288.

TSCHUMPERLIN K., ERDIN D., LEUENBERGER H., KUNZI N.(2001): Production parameters in a suckler cow system with Simmental and Angus cows on alpine pastures. Agrarforschung, 8, 4, 168-173.

ZEČEVIĆ B. (1986): Ispitivanje uticaja ukrštanja domaćeg šarenog govečeta sa crvenim holštajnom na osobine mlečnosti i plodnosti.Magistarski rad, Poljoprivredni fakultet, Beograd.

Izveštaji o sprovedenim merama selekcije na teritoriji Republike Srbije u 2004-oj i 2005-oj godini - Institut za stočarstvo - Beograd-Zemun.

Cattle encyclopedia: (www.Cattlenetwork.net)

Received 31 May 2009; accepted for publication 15 August 2009 